\title{
TINJAUAN YURIDIS TERHADAP PERKEMBANGAN ALAT BUKTI DALAM PENANGGULANGAN TINDAK PIDANA PENCUCIAN UANG
}

\author{
Alcadini Wijayanti ${ }^{1}$ RB Sularto ${ }^{2}$
}

\begin{abstract}
ABSTRAK
Penelitian ini bertujuan untuk menjelaskan Laporan Hasil Analisis (LHA) merupakan bagian dari alat bukti dalam penanggulangan Tindak Pidana Pencucian Uang (TPPU). Tujuan lainnya untuk mengetahui pembaharuan pembuktian dalam alat bukti dalam penanggulangan Tindak Pidana Pencucian Uang (TPPU) dimasa yang akan datang. Penelitian ini menggunakan metode penilitan yuridis normatif, yaitu penelitian yang dilakukan untuk mengkaji atau menganalisis berdasarkan metode pendekatan perundang-undang (statue approach) dan perbandingan hukum (comparative approach). Keseluruhan bahan hukum primer disusun secara sistematis dan dianalisis menggunakan analisis kualitatif. Hasil penelitian ditemukan bahwa Pertama,Secara yuridis LHA PPATK bukanlah alat bukti yang dapat dalam TPPU akan tetapi dapat menjadi alat bukti untuk menambah terangnya suatu perkara. Kedua, pembaharuan pembuktian dalam alat bukti dalam penanggulangan Tindak Pidana Pencucian Uang (TPPU) dimasa yang akan datang dapat dilakukan, seperti LHA PPATK dapat dimasukkan tergolong sebagai alat bukti dalam RUUKUHAP.
\end{abstract}

Kata Kunci: Tindak pidana, pencucian uang, alat bukti baru

\footnotetext{
${ }^{1}$ Mahasiswa Program Studi Magister Ilmu Hukum UNDIP
}

${ }^{2}$ Dosen Program Studi Magister Ilmu Hukum UNDIP 


\section{A. Latar Belakang}

Modus penyimpanan hasil kejahatan yang selama ini rapi sedikit demi sedikit telah tersingkap tabir gelapnya. Pergerakkan progresif beberapa lembaga penegak hukum telah mengalami perkembangan yang sangat signifikan. Peran yang sentral sebagai penyuplai laporan transaksi keuangan telah dibuktikan oleh Pusat Peloporan Analisi Transaksi Keuangan (PPATK) dengan memberikan beberapa laporan rekening mencurigakan yang dimiliki para pejabat negara atau individu yang diduga melakukan kejahatan tindak pidana pencucian uang yang diatur di dalam UU No. 8 Tahun 2010 tentang Pencegahan dan Pemberantasan Tindak Pidana Pencucian Uang, selanjutnya disebut TPPU. ${ }^{3}$

Kasus terhangat yang akhir-akhir ini dimuat di berbagai media cetak dan elektronik sehubungan dengan pemberitaan seorang polisi bernama Labora Siturus. Perputaran tranksasi di beberapa rekeningnya mencapai $\mathrm{Rp}$.

${ }^{3}$ http://m.jakartapress.com/read/detail/8425/ rekening-gendut-pns-untuk-danai-politik/, diakses 6 Juni 2013.
1,5 triliun, angka nominal yang sangat fantastis telah dicetak oleh seorang polisi berpangkat Ajung Inspetur Satu (Aiptu), meskipun rekening tersebut sebenarnya berasal dari bisnis perusahaan keluarga. $^{4} \quad$ Namun demikian, Labora Sitorus tetap dijadikan tersangka oleh pihak kepolisian dikarenakan adanya dugaan pelanggaran atas dua perusahaannya yaitu PT. Seno Adi Wijaya dan PT Rotua, telah melanggar hukum. PT SAW diduga menimbun bahan bakar minyak, sedangkan PT. Rotua diduga melakukan illegal logging. ${ }^{5}$

Laporan PPATK juga terbukti ampuh untuk membongkar modus kejahatan lain yang menimpa pegawai pajak Dhana Widhyatmika dengan jeratan pasal-pasal yang disangkakan oleh pihak Kejaksaan Agung terhadap Dhana yaitu 3, 5, 11, 12 a dan b, Pasal

${ }^{4}$ http://www.tempo.co/read/news/2013/05/1 7/063481277/Punya-60-Rekening-AiptuLabora-Sitorus-Menjawab, diakses 6 Juni 2013.

${ }^{5}$ Loc.cit. 
B Undang-Undang Tindak Pidana Korupsi dan Pasal 3 dan 4 TPPU. ${ }^{6}$

Sebuah pernyataan patut dikemukakan, apakah laporan PPATK dapat dijadikan alat bukti untuk melakukan penuntutan terhadap seseorang atau badan hukum yang diduga telah melakukan tindak pidana oleh institusi penegak hukum? Dalam TPPU seseorang dapat dituntut apabila terdapat tindak pidana asal (predicate crime) terlebih dahulu misalkan korupsi, perdagangan orang, illegal logging dan lain-lain. Sedangkan tindak pidana turunannya (underlying crime) adalah TPPU. Menurut Barda Nawawi Arif, predicate crime atau predicate offence adalah delik-delik yang menghasilkan criminal proceeds atau hasil kejahatan yang kemudian dicuci. $^{7}$

Perdebatan mengenai alat bukti juga menjadi public discourse berkaitan dengan tindak pidana terorisme. Dengan hanya menggunakan laporan intelejen sudah

6http://nasional.kompas.com/read/2012/03/0 2/21462593/Dhana.Widyatmika.Ditahan.Keja ksaan.Agung, diakses 6 Juni 2013.

7 Ivan Yusitavana et al, 2010, Tindak Pidana Pencucian Uang di Pasar Modal, Ghalia Indonesia, Jakarta, hal, 54. dapat dijadikan bukti permulaan untuk melakukan penututan terhadap para pihak yang diduga melakukan tindak pidana terorisme, meskipun penetapan sudah dapat atau diperoleh bukti permulaan yang cukup harus melalui proses pemeriksaan oleh Ketua atau Wakil Ketua Pengadilan negeri yang dilaksanakan secara tertutup dalam waktu paling lama 3 (tiga) hari. Apabila dalam pemeriksaan ini didapati adanya permulaan yang cukup, maka Ketua Pengadilan segera memerintahkan dilaksanakan penyidikan. ${ }^{8}$ Sementara laporan, menurut Pasal 1 angka 24 UU No. 8 Tahun 1981 tentang Kitab UndangUndang Acara Pidana, selanjutnya disebut KUHAP, adalah "pemberitahuan yang disampaikan oleh seorang karena hak atau kewajiban berdasarkan undang-undang kepada pejabat yang berwenang tentang telah atau sedang atau diduga akan terjadinya peristiwa pidana."

8 Lihat Pasal 26 Peraturan Pemerintah Pengganti Undang-Undang Nomor 1 Tahun 2002 tentang Pemberantasan Tindak Pidana Terorisme, yang telah disahkan menjadi Undang-Undang (Lembaran Negara Republik Indonesia Tahun 2003 Nomor 45, Tambahan Lembaran Negara Republik Indonesia Nomor 4284. 
Dapat dimaknai disini, bahwa laporan tidak dapat dijadikan alat bukti berdasarkan KUHAP.

Berdasarkan uraian tersebut maka permasalahan yang ingin diketahui dalam penelitian ini adalah Pertama,Apakah Laporan Hasil Analisis (LHA) merupakan bagian dari alat bukti dalam penanggulangan Tindak Pidana Pencucian Uang (TPPU) dan Kedua, Bagaimana pembaharuan pembuktian dalam alat bukti dalam penanggulangan Tindak Pidana Pencucian Uang (TPPU) dimasa yang akan datang?

\section{Metode Penelitian}

Metode pendekatan yang digunakan di dalam penelitian ini adalah metode pendekatan perundangundangang (statue approach) dan perbandingan/komparatif (comparative approach). Metode pendekatan perundang-undangan ini dilakukan dengan melakukan analisis terhadap semua perundang-undangan dan regulasi yang berkaitan dengan alat bukti dengan mencari ratio legis dan dasar antologis lahirnya undang- undang. ${ }^{9}$ Hal ini dilakukan untuk menangkap kandungan filosofis yang terkandung di dalam produk undangundang dan regulasi yang berguna untuk menyimpulkan ada tidaknya benturan filosofis antar undangundang dan regulasi tersebut. ${ }^{10}$

Selanjutnya pendekatan komparatif yaitu pendekatan yang dilakukan dengan membandingkan undangundang yang berlaku saat ini dimana di dalamnya mengatur tentang alat bukti baik undang-undang bersifat umum maupun khusus dengan membandingkan undang-undang yang mengatur hal yang sama dari negara Inggris dan Belanda. ${ }^{11}$ Negara Inggris dipilih sebagai perwakilan dari sistem Anglo-Saxon (common law system) dan Negeri Belanda sebagai perwakilan dari sistem Eropa Kontinental. Dasar pemikiran pemilihan dari kedua negara tersebut dikarenakan di satu sisi sistem hukum Indonesia mendapatkan pengaruh perkembangan hukum yang terjadi di

\footnotetext{
9 Peter Mahmud Marzuki, 2013, Penelitian Hukum, Kencana Prenada Media Group, Jakarta, hal. 133.

${ }^{10}$ Ibid, hal. 134.

${ }^{11}$ Ibid, hal. 135.
} 
negara-negara sistem Anglo-Saxon akibat dari perkembangan zaman, di sisi lain sistem hukum Indonesia menganut sistem hukum Eropa Kontinental warisan kolonial Belanda. Penelitian komparatif ini untuk memperoleh persamaan dan perbedaan diantara undang-undang dan regulasi tersebut. $^{12}$

\section{Kerangka Teori}

Di dalam penelitian hukum setingkat tesis diharuskan mengupas suatu isu hukum yang dapat diterapkan secara akademik dan praktik seyogyanya mengacu pada acuan teori hukum bersifat normatif. Menurut J.J.H. Bruggink teori hukum adalah "seluruh pernyataan yang saling berkaitan dengan sistem konseptual aturan-aturan hukum dan putusanputusan hukum, dan sistem tersebut untuk sebagian yang penting dipositifkan."13 Definisi tersebut bermakna bahwa kelesuruhan, koherensi dan kesatuan dari suatu produk hukum merupkan pernyataan

${ }^{12}$ Loc.cit.

13 Salman, Otje., Anthon F. Susanto. Teori Hukum Mengingat, Mengumpulkan dan MembukaKembali. Bandung: Rafikatama, 2010, hal. 60 yang saling terkait yang dihasilkan melalui kegiatan teoritik dibidang hukum. $^{14}$

Di dalam hukum acara pidana terdapat berbagai macam asas-asas hukum acara pidana seperti peradilan cepat, sederhana, dan biaya ringan; praduga tidak bersalah; asas oportunitas, pemeriksaan pengadilan terbuka untuk umum; semua orang diperlakukan sama di depan hakim, peradilan dilakukan oleh hakim karena jabatannya dan tetap; tersangka/terdakwa berhak mendapat bantuan hukum; asas akusator dan inkisitor; pemeriksaan hakim yang langung dan lisan. ${ }^{15}$

Terdapat beberapa teori tetang pembuktian diantaranya: ${ }^{16} 1$ ). Conviction in Time, maksudnya adalah Sistem pembuktian yang menentukan salah tidaknya seorang terdakwa, semata-mata ditentukan oleh penilaian "keyakinan" hakim. 2). ConvictioninRaisonee, maksudnya

\footnotetext{
${ }^{14}$ Ibid.

${ }^{15}$ Hamzah, Andi, Hukum Acara, Op.cit, hal. 12-25.

16 Harahap, Yahya M. Pembahasan Permasalahan dan Penerapan KUHAP Pemeriksaan Sidang Pengadilan, Banding, dan Peninjauan Kembali. Jakarta: Sinar Grafika, 2009, hal. 277-280.
} 
merupakan Keyakinan hakim dalam menjatuhkan putusan tetap memiliki peran yang dominan tetapi harus didukung oleh alasan-alasan yang jelas. Hakim wajib menguraikan dan menjelaskan alasan-alasan apa yang mendasari keyakinannya atas kesalahan terdakwa. 3). Pembuktian menurut undang-undang secara positif. Dalam sistem ini, hakim seolah-olah "robot" pelaksana daripada undangundang yang tak memiliki hati nurani. Jadi, apabila terdakwa terbukti bersalah berdasar alat bukti yang sah menurut undang-undang maka hakim dapat segera memutuskan bahwa terdakwa bersalah tanpa adanya peran keyakinan hakim. DAN 4). Pembuktian menurut undang-undang secara negatif. Penggabungan antara keyakinan hakim dan alat bukti yang sah menurut undang-undang untuk menentukan salah tidaknya terdakwa.Sistem pembuktian menurut undang-undang secara negatif adalah sistem yang diterapkan di Indonesia.

\section{B. Hasil Penelitian Dan Pembahasan}

1. Kajian Terhadap Laporan Hasil (LHA) Analisis PPATK Sebagai

\section{Bagian dari Alat Bukti dalam Penanggulangan Tindak Pidana Pencucian Uang (TPPU)}

Menurut Yenti Ganarsih tujuan daripada UU TPPU adalah sebagai langkah awal bagi pelaku untuk menikmati hasil kejahatan dan kemudian diharapakan pelaku kejahatan utama (the main offender) dapat ditangkap. Tujuan lainnya adalah untuk mencegah lembaga keuangan agar tidak digunakan sebagai sarana pencucian uang dalam lingkup nasional dan internasional. ${ }^{17}$ Dengan demikian prinsip penegakan hukumnya adalah bukan hanya follow the suspect melainkan juga follow the money. ${ }^{18}$

\footnotetext{
17 Yenti Ganarsih, Kriminalisasi Pencucian Uang (Money Laundering), Program Pasca Sarjana Universitas Indonesia, Jakarta, 2003 hal. 66.

${ }^{18}$ Fithriadi Muslim \& Edi Nasution, Menjerat Koruptor Dengan Undang-Undang Tindak Pidana Pencucian Uang, Makalah ini disampaikan pada Seminar Nasional dan Dialog Interaktif dengan tema "Apa dan Mengapa Tindak Pidana Korupsi dan Pencucian Uang Merajalela" yang diselenggarakan oleh Lembaga Pengabdian Kepada Masyarakat (LPKM) Universitas Negeri Padang bekerjasama dengan Pro Justitia Institute Jakarta dan Harian Umum Singgalang di Hotel Pangeran Beach, Padang pada tanggal 19 November 2011 hal. 4.
} 
Transaksi

Keuangan

Mencurigakan" (selanjutnya di TKM) adalah transaksi yang menyimpang dari kebiasaan atau tidak wajar dan tidak selalu terkait dengan tindak pidana tertentu. Istilah 'transaksi yang mencurigakan' atau suspicious transaction report (STR)dalam terminologi anti pencucian uang digunakan pertama kali oleh the FinancialAction Task Force on Money Laundering (FATF) dalam the FortyRecommendations tentang pemberantasan tindak pidana pencucian uang. ${ }^{19}$

Transaksi keuangan yang mencurigakan adalah transaksi yang menyimpang dari profil dan karakteristik nasabah serta kebiasan nasabah termasuk transaksi yang patut diduga dilakukan dengan tujuan untuk menghindari pelaporan transaksi yang bersangkutan yang wajib dilakukan oleh penyedia jasa keuangan (PJK). ${ }^{20}$

19 PPATK, 2003, Pedoman Identifikasi Transaksi Keuangan Mencurigakan bagi Penyedia Jasa Keuangan, PPATK, Jakarta, hal. 3.

${ }^{20}$ http://repository.usu.ac.id/bitstream/12345 6789/35146/3/Chapter\%20II.pdf, diakses 9 Juli 2013.
TKM tidak mempunyai spesifikasi khusus dalam proses transaksi karena hal ini bergantung daripada variasi variasi dan perkembangan jasa dan instrumen keuangan yang ada. Meskipun demikian, terdapat ciri-ciri umum dari TKM yang dapat dijadikan acuan, antara lain: ${ }^{21}$

a. Tidak memiliki tujuan ekonomis dan bisnis yang jelas;

b. Menggunakan uang tunai dalam jumlah yang relatif besar dan/atau dilakukan secara berulang-ulang di luar kewajaran;

c. Di luar kebiasaan dan kewajaran aktivitas transaksi nasabah.

Menurut Pasal 1 angka 5 UU Transaksi Keuangan Mencurigakan adalah:

a. Transaksi Keuangan yang menyimpang dari profil, karakteristik, atau kebiasaan pola Transaksi dari Pengguna Jasa yang bersangkutan;

b. Transaksi Keuangan oleh Pengguna Jasa yang patut diduga dilakukan dengan tujuan untuk menghindari pelaporan Transaksi yang bersangkutan yang wajib dilakukan

\footnotetext{
${ }^{21}$ Ibid, hal. 3-4.
} 
oleh Pihak Pelapor sesuai dengan ketentuan Undang-Undang ini;

c. Transaksi Keuangan yang dilakukan atau batal dilakukan dengan menggunakan Harta Kekayaan yang diduga berasal dari hasil tindak pidana; atau

d. Transaksi Keuangan yang diminta oleh PPATK untuk dilaporkan oleh Pihak Pelapor karena melibatkan Harta Kekayaan yang diduga berasal dari hasil tindak pidana.

Menurut Kamus Besar Bahasa Indonesia (KBBI), laporan adalah segala sesuatu yang dilaporkan atau berita. ${ }^{22}$ Black's law dictionary mendefinisikan laporan atau report adalah penyajian fakta secara resmi baik lisan maupun tertulis atau suatu rekomendasi untuk melakukan perbuatan (A formal oral or written presentation of facts or a recommendation for action). ${ }^{23}$ Menurut KUHAP, laporan adalah pemberitahuan yang disampaikan oleh seseorang karena hak atau

${ }^{22}$ http://kbbi.web.id/lapor, diakses 10 Juli 2013.

${ }^{23}$ Henry Black Campbell, 2009, Black's law Dictionary, $9^{\text {th }}$ edition, West Publishing Co., St. Paul-Minnessota, hal. 1414 kewajibannya berdasarkan undangundang kepada pejabat yang berwenang tentang telah atau sendang atau diduga akan terjadinya peristiwa pidana. Berpijak dari definisi-definisi diatas, laporan adalah penyampaian fakta oleh seseorang atas dasar hak dan kewajibannya berdasar undang-undang mengenai segala sesuatu berkaitan dengan peristiwa pidana yang diduga telah, sedang, dan akan terjadi.

Berdasar Pasal 184 KUHAP, alat bukti yang sah ialah keterangan saksi, keterangan ahli, surat, petunjuk, dan keterangan terdakwa. Merujuk Pasal tersebut, laporan bukanlah merupakan alat bukti bukti. Sedangkan menurut Pasal 73 TPPU alat bukti yang sah dalam pembuktian tindak pidana Pencucian Uang ialah: a. alat bukti sebagaimana dimaksud dalam Hukum Acara Pidana; dan/atau b. alat bukti lain berupa informasi yang diucapkan, dikirimkan, diterima, atau disimpan secara elektronik dengan alat optik atau alat yang serupa optik dan dokumen. LHA sebagai alat bukti tidaklah diatur di dalam UU TPPU, hanya sekedar laporan analasis transaksi keungan mencurigakan yang 
dapat dijadikan petujuk untuk aparat penegak hukum baik kepolisian, kejaksaan, dan pengadilan. Oleh karena itu banyak pihak yang tidak setuju LHA merupakan alat bukti dalam TPPU.

Kesimpulannya, LHA PPATK bukanlah alat bukti secara yuridis sebab hanya informasi yang berguna untuk menambah terangnya suatu perkara pidana yang dapat digunakan bagi aparat penegak hukum terutama bagi penyidik untuk menemukan apakah transaksi mencurigakan dari seseorang terindikasi adanya perbuatan melawan hukum (wedderrechtelijke daad $^{24}$ dalam bentuk TPPU. LHA PPATK bukanlah proses final menjadi alat bukti meskipun laporan itu ditempuh dengan tahap verifikasi dari penilaian akhir dari seluruh proses identifikasi masalah, analisis dan evaluasi yang dilakukan secara independen, objektif, dan profesional untuk disampaikan kepada penyidik.

\footnotetext{
${ }^{24}$ W.A. Engelbrecht, 1954, De Wetboeken Wetten en Verorderingen Benevensi De Voorlopige Grondwet van de Republiek Indonesië, A.W. Sijthoff's Uitgeversmij N.V., Leiden, hal. 366 dan 1048.
}

\section{Pembaharuan Pembuktian} Dalam Penanggulangan Tindak Pidana Pencucian Uang Di Masa Yang Akan Datang

$\underline{\text { Kajian Studi Perbandingan Alat }}$ Bukti Tindak Pidana Pencucian Uang

a. Alat bukti TPPU di Amerika

Pemerintah Federal Amerika Serikat membuat kebijakan TPPU untuk menyelamatkan sistem keuangan dari penyelahgunaan kejahatan financial termasuk dana terorisme, pencucian uang dan juga aktivitas kejahatan lainnya. Koherensi dari peraturan perundang-undangan penegakan hukum melawan kejahatan finansial dimulai dengan disahkannya Undang-Undang Rahasia Bank atau Bank Secrecy Act (selanjutnya disebut BSA).

BSA ini diundangkan pada tahun 1970 dan telah menjadi undangundang paling penting di Amerika untuk melawan TPPU. ${ }^{25}$ Sejak saat itu beberapa undang-undang penting telah diundangkan untuk memperkuat dan mengamandemen BSA dengan tujuan meningkatkan penegakan hukum dan

\footnotetext{
${ }^{25}$ http://www.fincen.gov/news room/aml his tory.html, diakses 13 Juli 2013.
} 
peraturan perundang-undang sebagai landasan hukum bagi berdirinya badan-badan atau instansi-instasi demi mendukung program pemberantasan TPPU.

b. Alat Bukti TPPU di Jerman

Di Jerman UU TPPU (Geldwäschegesetz - GwG) disebut juga UU Deteksi Hasil Kejahatan Berat diadopsi pada tanggal 24 September tahun 1993 dan mulai berlaku pada tanggal 29 November 1993. Ada dua perubahan utama: pertama dengan UU tentang Peningkatan Upaya Memerangi Kejahatan Terorganisir (Act on Improving Measures to Combat Organised Crime) 4 Mei 1998 yang mulai berlaku pada tanggal 9 Mei 1998 dan kedua oleh Undang-Undang tentang Pemberantasan Pencucian Uang dan Pencegahan Pendanaan Terorisme (Suppression of Money Laundering and Combating the Financing of Terrorism) pada tanggal 8 Agustus 2002, yang mulai berlaku pada 15 Agustus 2002. ${ }^{26}$

26 European Banking Federation, Money Laundering Legislation, National Measures, Fraud Working Group, Brussels - October 2002 Hal. 20-23
Pasal 261 (Pencucian Uang, menyembunyikan aset ilegal) KUHP (Strafgesetzbuch/StGB) mengatur sanksi pidana dikenakan pada orang yang sadar atau kelalaian berpartisipasi dalam pencucian uang. Bagian Pasal 261 StGB mulai berlaku pada 22 September 1992 dan telah beberapa kali diubah sejak. Antara lain, daftar pelanggaran diperpanjang oleh masing-masing dari perubahan tersebut. ${ }^{27}$

Tindak Pidana Pencucian Uang menetapkan bahwa laporan transaksi yang mencurigakan (Suspicious Transaction Record/STR) harus disampaikan oleh lembaga yang memiliki kewenangan penuntutan. Menurut struktur federal Jerman, STR harus dikirimkan kepada polisi atau kejaksaan di negara federal. Sebuah salinan dari setiap STR harus dikirim ke Kantor Investigasi Federal Kriminal (Federal Office of Criminal Investigation) atau BKA (Bundeskriminalam) dimana Unit Sentral untuk Laporan Transaksi Keuangan Mencurigakan (Financial

\footnotetext{
${ }^{27}$ Loc. cit.
} 
Intelligence Unit - FIU) atau PPATK Jerman telah dibentuk sebagai konsekuensi dari 2002 amandemen UU Money Laundering. ${ }^{28}$ Pengaturan adanya FIU ini mirip dengan apa yang diatur di dalam UU No. 15 Tahun 2002 Tentang TPPU di Indonesia.

$\underline{\text { Konvensi-Konvensi PBB Berkaitan }}$ dengan Tindak Pidana Pencucian Uang yang diratifikasi oleh Indonesia

Berikut ini adalah beberapa konvensi Internasional yang telah diratifikasi oleh Indonesia menjadi hukum nasional terkait dengan TPPU.

1. United Nations Convention Against Illicit Traffic in Narcotic Drugs and Psychotrophic $1988^{29}$

Konvensi 1998 diratifikasi menjadi UU No. 17 Tahun 1997 tentang United Nations Convention Against Illicit Traffic in Narcotic Drugs and Psychotrophic 1988. Tujuan utama konvensi ini dijabarkan di Pasal 2 yaitu

\footnotetext{
${ }^{28}$ Loc.cit.

${ }^{29}$ Jimmy Gurule, The 1988 U.N. Convention Against Illicit Traffic in Narcotic Drugs and Psychotropic Substances $-A$ Ten Year Perspective: Is International Cooperation Merely Illusory?, Fordham International Law Journal, Volume 22, Issue 1 1998, The Berkeley Electronic Press (bepress). http://ir.lawnet.fordham.edu/ilj hal. 81-84.
}

untuk mempromosikan kerjamasama antar negara anggota PBB sehingga mereka lebih mampu dan efektif untuk menanggulangi berbagai macam perdagangan narkotika dan pskikotropika dalam dimensi internasional.

2. International Convention for the Suppression of the Financing of Terrorism 1999; ${ }^{30}$

UU No. 6 Tahun 2006 tentang Pengesahan International Convention for the Suppression of the Financing of Terrorism 1999.

3. Undang-undang Nomor 7 Tahun 2006 tentang Pengesahan United Nation Convention Against Corruption 2003

Arti penting lainnya dari ratifikasi Konvensi tersebut adalah: ${ }^{31}$

untuk meningkatkan kerja sama internasional khususnya dalam melacak, membekukan, menyita, dan mengembalikan aset-aset hasil tindak pidana korupsi yang ditempatkan di luar negeri; - meningkatkan kerja sama

\footnotetext{
${ }^{30}$ http://www.un.org/law/cod/finterr.htm, diakses 18 Juli 2013

31 Penjelasan Umum dari Undang-undang Nomor 7 Tahun 2006 tentang Pengesahan United Nation Convention Against Corruption 2003.
} 
internasional dalam mewujudkan tata pemerintahan yang baik;

- meningkatkan kerja sarna internasional dalarn pelaksanaan perjanjian ekstradisi, bantuan hukurn tirnbal balik, penyerahan narapidana, pengalihan proses pidana, dan kerja sarna penegakan hukurn;

- mendorong terjalinnya kerja sarna teknik dan pertukaran informasi dalam pencegahan dan pemberantasan tindak pidana korupsi di bawah payung. kerja sama pembangunan ekonomi dan bantuan teknis pada lingkup bilateral, regional, dan multilateral; dan

- harmonisasi peraturan perundangundangan nasional dalam pencegahan dan pemberantasan tindak pidana korupsi sesuai dengan Konvensi ini.

Pembuktian dan Alat Bukti dalam Rancang Kitab Undang-Undang Hukum Acara Pidana (RUUKUHAP) Rancang Kitab Undang-Undang Hukum Acara Pidana dalam Pasal 174 mengatur tentang Hakim dilarang menjatuhkan pidana kepada terdakwa, kecuali apabila hakim memperoleh keyakinan dengan sekurang-kurangnya 2 (dua) alat bukti yang sah bahwa suatu tindak pidana benar-benar terjadi dan terdakwalah yang bersalah melakukannya. ${ }^{32}$ Menurut penjelasan pasal ini, yang dimaksudkan untuk menjamin tegaknya kebenaran, keadilan, dan kepastian hukum bagi seseorang. Dalam acara pemeriksaan cepat, keyakinan hakim cukup didukung satu alat bukti yang sah.

Pasal 175 ayat Ayat menyatakan bahwa alat bukti yang sah sebagaimana dimaksud pada ayat (1) harus diperoleh secara tidak melawan hukum dan ayat (3) menegaskan bahwa hal yang secara umum sudah diketahui tidak perlu dibuktikan. ${ }^{33}$

Pasal 175 ayat (1) mengatur tentang alat bukti Alat bukti yang sah mencakup, yang terdiri dari:barang bukti; surat-surat; bukti elektronik; keterangan seorang ahli; keterangan seorang saksi; keterangan terdakwa; pengamatan hakim

\footnotetext{
32 Bandingkan dengan Pasal 183 KUHAP.

33 Bandingkan dengan Pasal 184 ayat (2) KUHAP.
} 


\section{Simpulan Dan Saran}

Dari keseluruhan uraian dan bahasan tersebut maka dapat disimpulkan bahwa

1. Secara yuridis LHA PPATK bukanlah alat bukti yang dapat dalam TPPU akan tetapi dapat menjadi alat bukti untuk menambah terangnya suatu perkara. Laporan ini dapat dijadikan acuan sebagai jalan terang guna menulusuri untuk menentukan tersangka dalam tingkat penyidikan, penuntutan, dan persidangan untuk menambah terangnya kasus TPPU sehingga dapat diketahui dari mana hasil harta kekayaan. Alat bukti yang berlaku di dalam TPPU adalah alat bukti yang berlaku di dalam KUHAP dan alat bukti yang sah dalam pembuktian tindak pidana Pencucian Uang ialah: a. alat bukti sebagaimana dimaksud dalam Hukum Acara Pidana; dan/atau b. alat bukti lain berupa informasi yang diucapkan, dikirimkan, diterima, atau disimpan secara elektronik dengan alat optik atau alat yang serupa optik dan dokumen merupakan terobosan terbaru, tidak hanya di bidang hukum untuk mengatasi cyber crime, namun juga berupa terobosan dalam perkembangan alat bukti. Alat bukti tambahan ini merupakan alat bukti yang diatur di dalam UU No. 11 Tahun 2008 tentang Informasi dan Transaksi Elektronik (ITE).

2. LHA PPATK dapat dimasukkan tergolong sebagai alat bukti dalam RUUKUHAP. Laporan ini akan sangat berguna untuk membongkar suatu TPPU sebagaimana diatur di dalam Pasal 2 ayat (1), terutama tindak pidana korupsi yang semakin susah untuk diberantas di Indonesia.TPPU adalah tindak pidana yang menjadi sorotan dunia Internasional. Oleh karena itu Indonesia telah mewujudkan komimentnya dengan meratifikasi beberapa konvensi PBB yang berkaitan dengan TPPU, antara lain: United Nations Convention Against Illicit Traffic in Narcotic Drugs and Psychotrophic 1988, International Convention for the Suppression of the Financing of 
Terrorism 1999, United Nation Convention Against Corruption 2003. United Nations Convention Against Transnational Organized Crime (2000) atau Palermo Convention.Bertebarannya alat bukti yang diatur oleh UndangUndang khusus walaupun UndangUndang tersebut tetap mengacu pada alat bukti yang berlaku di KUHP, hal ini menunjukkan atas keberlakuannya asa hukum yaitu lex specialis derogate lex genaralis atau aturan hukum bersifat khusus mengesampingkan aturan hukum bersifat umum. Undang-undang khusus memuat pula alat bukti dari UU No. 11 Tahun 2008 tentang Informasi dan Transaksi Elektronik (ITE).

\section{Saran}

1. LHA PPATK seyogya langsung dapat dijadikan alat bukti bagi pemilik transaksi mencurigakan yang terindikasi melakukan TPPU untuk dijadikan tersangka oleh penyidik dengan pengawasan dari pihak kejaksaan seperti halnya pemberantasan TPPU di Amerika
Serikat dan Jerman terutama ditujukan untuk mengefektifkan pemberantasan tindak pidana korupsi, narkoba, dan terorisme.

2. Sistem pembuktian terbalik sebaiknya dapat diterapkan secara utuh dengan berpedoman pada Pasal 77 dan 78 UU TPPU dimana untuk kepentingan pemeriksaan di sidang pengadilan, terdakwa wajib membuktikan bahwa harta kekayaannya bukan merupakan hasil tindak pidana dan hakim memerintahkan terdakwa agar membuktikan bahwa harta kekayaan yang terkait dengan perkara bukan berasal atau terkait dengan tindak pidana.

\section{Daftar Pustaka}

European Banking Federation, Money Laundering Legislation, National Measures, Fraud Working Group, Brussels - October 2002

Fithriadi Muslim \& Edi Nasution, Menjerat Koruptor Dengan Undang-Undang Tindak Pidana Pencucian Uang, Makalah, Seminar Nasional dan Dialog Interaktif di Hotel Pangeran Beach, Padang pada tanggal 19 November 2011 
Harahap, Yahya M. Pembahasan

Permasalahan dan Penerapan KUHAP Pemeriksaan Sidang Pengadilan, Banding, dan Peninjauan Kembali. Jakarta: Sinar Grafika, 2009

Henry Black Campbell, 2009, Black's law Dictionary, $9^{\text {th }}$ edition, West Publishing Co., St. PaulMinnessota

Ivan Yusitavana et al, 2010, Tindak Pidana Pencucian Uang di Pasar Modal, Ghalia Indonesia, Jakarta

Jimmy Gurule, The 1988 U.N. Convention Against Illicit Traffic in Narcotic Drugs and Psychotropic Substances $-A$ Ten Year Perspective: Is International Cooperation Merely Illusory?, Fordham International Law Journal, Volume 22, Issue 1 1998, The Berke- ley Electronic Press (bepress).

http://ir.lawnet.fordham.edu/ilj

Peraturan Pemerintah Pengganti Undang-Undang Nomor 1 Tahun 2002 tentang Pemberantasan Tindak Pidana Terorisme, yang telah disahkan menjadi UndangUndang (Lembaran Negara Republik Indonesia Tahun 2003 Nomor 45, Tambahan Lembaran Negara Republik Indonesia Nomor 4284.

Peter Mahmud Marzuki, 2013, Penelitian Hukum, Kencana Prenada Media Group, Jakarta

PPATK, 2003, Pedoman Identifikasi Transaksi Keuangan Mencurigakan bagi Penyedia Jasa Keuangan, PPATK, Jakarta, Salman, Otje., Anthon F. Susanto. Teori Hukum Mengingat,
Mengumpulkan dan MembukaKembali. Bandung: Rafikatama, 2010

Undang-undang Nomor 7 Tahun 2006 tentang Pengesahan United Nation Convention Against Corruption 2003.Penjelasan Umum dari

W.A. Engelbrecht, 1954, De Wetboeken Wetten en Verorderingen Benevensi De Voorlopige Grondwet van de Republiek Indonesië, A.W. Sijthoff's Uitgeversmij N.V., Leiden, http://www.fincen.gov/news_roo m/aml_history.html, diakses 13 Juli 2013.

Yenti Ganarsih, Kriminalisasi Pencucian Uang (Money Laundering), Program Pasca Sarjana Universitas Indonesia, Jakarta, 2003

Media Online

http://kbbi.web.id/lapor, diakses 10 Juli 2013.

http://m.jakartapress.com/read/detail/8 425/rekening-gendut-pns-untukdanai-politik/, diakses 6 Juni 2013.

http://nasional.kompas.com/read/2012/ 03/02/21462593/Dhana.Widyatm ika.Ditahan.Kejaksaan.Agung, diakses 6 Juni 2013.

http://repository.usu.ac.id/bitstream/12 3456789/35146/3/Chapter\%20II. pdf, diakses 9 Juli 2013.

http://www.tempo.co/read/news/2013/ 05/17/063481277/Punya-60Rekening-Aiptu-Labora-SitorusMenjawab, diakses 6 Juni 2013. http://www.un.org/law/cod/finterr.htm, diakses 18 Juli 2013 